\title{
蔟黎苗宿重金属转运蛋白HMA5基因在共生结瘤中的 功能分析
}

\author{
杨墨 ${ }^{\dagger}$, 徐铭英 $^{\dagger}$, 张璐, 丑敏霞 ${ }^{*}$ \\ 西北农林科技大学生命科学学院, 旱区作物逆境生物学国家重点实验室, 农业与环境微生物学陕西省重点实验室, 咸阳 712100 \\ $\dagger$ 同等贡献 \\ *联系人, E-mail: minxia104@nwafu.edu.cn
}

2021-02-08 收稿, 2021-03-09 修回, 2021-03-10 接受, 2021-03-11 网络版发表

国家自然科学基金(41977052)和陕西省重点研发计划(2020ZDLNY07-09)资助

\begin{abstract}
摘要 重金属转运ATP酶(heavy metal transporting ATPase, HMA)主要参与植物体内重金属的转运. 前期研究发现, HMA5 基因与萛缩铜胁迫及共生结瘤相关。为探明豆科植物根瘤中的铜离子吸收、转运及平衡机制，本研究以模 式豆科植物箐蔡苜宿 (Medicago truncatula, Mt) 为材料，对其HMA5同源基因MTR_8g079250在共生结瘤中的功能 进行了初步研究. 亚细胞定位分析表明, MTR_8g079250主要定位于细胞膜和细胞核上; GFP::MTR_8g079250融合 表达分析显示, MTR_8g079250主要在根瘤的分生区、侵染区、皮层和根的中柱、根冠表达，RNAi沉默目的基因 后对共生固氮表型没有产生明显影响。然而，目的基因过表达植株的鲜重和单株根瘤数目较野生型明显降低，侵 染线和根瘤原基也显著减少; 透射电子显微镜分析表明, 根㾪细胞中含有少量的类菌体且形状不规则, 环类菌体空 间增大，呈现出早衰的迹象； qRT-PCR结果显示，结瘤标志性基因NIN、DMI1、ENOD11和豆血红蛋白基因的表达 水平均有不同程度的下调，豆血红蛋白基因的表达水平也有所下调。这些结果表明, MTR_8g079250过表达对共生 结瘤有抑制作用。
\end{abstract}

关键词粼萛萡, HMA5, 共生固氮, 定位分析, 过表达

豆科植物之所以能够在氮素限制的环境中生长, 是因为它们与土壤中的根瘤菌进化出了共生关系，导 致形成新的器官, 即根瘤. 在根瘤中, 根瘤菌通过生物 固氮将氮素还原为氨供给宿主豆科植物，用以交换其 所需要的物质和能量. 在此共生体系中, 豆科植物可以 为根瘤菌提供金属微量元素 ${ }^{[1]}$. 铜作为生物体所必需的 微量矿质元素之一, 参与了植物的生长、发育及器官 分化过程. 在豆科植物-根瘤菌共生固氮过程中, 铜是 众多关键酶的辅助因子，如作为超氧化物歧化酶辅因 子参与根瘤中的自由基代谢, 作为细胞色素氧化酶辅 因子参与呼吸链电子传递过程等; 同时铜离子也是酪
氨酸酶的辅因子，对细菌的生长至关重要．有研究表 明，豆科植物与根瘤菌共生后会增强植物对重金属铜 的抗性, 例如在铜胁迫下接种根瘤菌, 可以缓解铜对植 物的生长抑制 ${ }^{[2]}$. 然而, 铜过量也会对共生固氮产生毒 害. 例如在铜过量的情况下, 根瘤的固氮区中会积累大 量的 $\mathrm{H}_{2} \mathrm{O}_{2}$, 导致固氮效率显著降低. 这是由于铜过量时 谷胱甘肽和过氧化氢酶不能及时清除植物产生的 $\mathrm{H}_{2} \mathrm{O}_{2}$, 从而损伤植物细胞 ${ }^{[3]}$. 由此可见, 铜含量过高或过 低都不利于植物的正常生长发育，会影响到包括共生 固氮在内的诸多生理过程，因此植物中的铜含量必须 维持在一定的生理范围内. 为此, 高等植物进化出了复

引用格式: 杨墨, 徐铭英, 张璐, 等. 䔳葱萛宿重金属转运蛋白HMA5基因在共生结瘤中的功能分析. 科学通报, 2021, 66: 3719-3731 Yang M, Xu M Y, Zhang L, et al. Functional analysis of heavy metal transporter HMA5 gene in symbiotic nodulation of Medicago truncatula (in Chinese) Chin Sci Bull, 2021, 66: 3719-3731, doi: 10.1360/TB-2021-0164 
杂的生理机制以维持细胞内铜稳态的平衡 ${ }^{[4]}$. 植物体通 过吸收、分布、利用、储存和外排等过程对金属离子 的平衡进行调控, 在调控的过程中重金属转运蛋白发 挥了重要作用. 植物体内与铜转运相关的蛋白包括 COPT转运蛋白、 $\mathrm{P}_{1 \mathrm{~B}}$ 型ATP酶、分子伴侣、ZIP转运蛋 白家族、麦根酸和烟酰胺等 ${ }^{[5]}$.

重金属转运ATP酶(heavy metal transporting ATPase, HMA) 是一种通过水解ATP跨膜运送重金属阳离 子的转运蛋白, 属于P-ATPase家族中的一个亚类. $\mathrm{HMA}$ 中的 $\mathrm{P}_{1 \mathrm{~B}}$ 被证实与重金属的转运相关, 可以选择性 吸收和运输植物生长发育所必需的金属离子 $\left(\mathrm{Cu}^{+}\right.$、 $\mathrm{Cu}^{2+} 、 \mathrm{Zn}^{2+}$ 和 $\left.\mathrm{Co}^{2+}\right)$ 和一些非必需的重金属离子 $\left(\mathrm{Cd}^{2+}\right.$ 和 $\left.\mathrm{Pb}^{2+}\right)^{[6-8]}$. 目前, 对拟南芥(Arabidopsis thaliana, At)、水 稻(Oryza sativa, Os)和黄瓜(Cucumis sativus, Cs)等植物 的HMA家族基因进行了较多研究 ${ }^{[9 \sim 14]}$, 对豆科植物中 包括HMA5在内的P-type ATPase的研究鲜有报道. 同 时, 豆科植物根瘤中的离子转运研究也并不多见, 许多 具体细节有待探明. 本实验室前期从天蓝苜宿中分离 到一个与铜胁迫及共生结瘤相关的HMA5基因，本研 究即以豆科模式植物静藜苜宿的HMA5基因为研究对 象，通过RNA干扰、过表达及表达定位等方法对其在 共生结瘤过程中的功能进行初步鉴定，为最终探明豆 科植物根瘤中的铜离子吸收、转运及平衡机制奠定 基础.

\section{1 材料与方法}

(i) 植物培养和处理. 以跻藜苜宿 (Medicago truncatula, Mt)A17为植物材料, 选取状态良好的种子用浓 硫酸处理 $10 \mathrm{~min}$, 无菌水清洗. $30 \%$ 的次氯酸钠溶液浸 泡种子 $8 \mathrm{~min}$, 无菌水清洗后 $28^{\circ} \mathrm{C}$ 摇床孵育 $3 \mathrm{~h}$. 种子平 铺在水琼脂培养基上, $28^{\circ} \mathrm{C}$ 黑暗萌发 $48 \mathrm{~h}$. 将发芽的种 子转移到无菌基质中(蛭石:珍珠岩 $=2: 1$ ). 实验设置3组, 分别加人硫酸铜至终浓度为 $0 、 50$ 和 $200 \mathrm{mg} / \mathrm{kg}$ 的. 室温 放置一周后装盆. 接种根瘤菌Sinorhizobium meliloti $1021\left(A_{600}=0.1\right)$ 于长出真叶的幼苗根部.

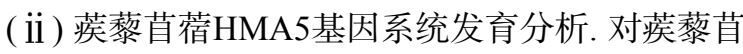
宿中的HMA5所有相关基因进行聚类分析构建系统发 育树. 系统发育分析选取的物种为: 拟南芥(Arabidopsis thaliana, At)、葡萄(Vitis vinifera, $\mathrm{Vv})$ 、水稻(Oryza sativa, Os)、黄瓜(Cucumis sativus, Cs)、卷柏(Lycophyte selaginella, Ls)、毛果杨(Populus trichocarpa, $\mathrm{Pt}) 、$ 高粱(Sorghum bicolor, $\mathrm{Sb})$. (iii) RNA的提取及反转录. 定期取祅藜苜宿转化 苗的根部样品 $0.25 \mathrm{~g}$, 锡䈃纸包严后液氮速冻, $-80^{\circ} \mathrm{C}$ 保 存. 使用TaKaRa MiniBEST Universal RNA Extraction Kit试剂盒进行RNA提取. 将获得的RNA, 使用HiScript II Q Select RT SuperMix反转录酶进行反转录, 获得 cDNA.

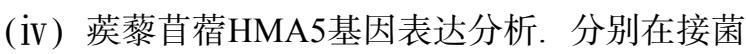
5、10、18、23和 $28 \mathrm{~d}$ 后提取 50 和 $200 \mathrm{mg} / \mathrm{kg}$ 硫酸铜处

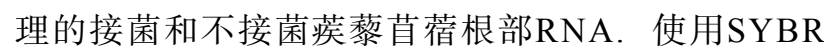
Green Real-time PCR Master Mix(Takara)进行qRTPCR. 所用引物为: $M T R \_8 g 079250-\mathrm{F}$ : ACTGTTGTTTTCTGCGTTATGG、MTR_8g079250-R: CAATGGCGTCACGTATGCT、MTR_8g012390-F: TGGTTTAGCTTTAGAGGAGG、MTR_8g012390-R: AGACACCAAGACATTAGCATC、MTR_5g010420-F: AGTTGGTGCATCTCAGGGTG、MTR_5g010420-R: GCTAGTGGATGTTCGCTGTTC. 在无酶PCR管中依次加人 $10 \mu \mathrm{L}$ SYBR GreenI Master Mix(Takara), $0.8 \mu \mathrm{L}$ P1、0.8 $\mu \mathrm{L}$ $\mathrm{P} 2 、 2 \mu \mathrm{L}$ cDNA模板, 用 $\mathrm{ddH}_{2} \mathrm{O}$ 补至 $20 \mu \mathrm{L}$. 用两步法 进行扩增. 第一步: $95^{\circ} \mathrm{C}$ 加热 $10 \mathrm{~min}$, 进行一个循环; 第 二步: $95^{\circ} \mathrm{C}$ 加热 $15 \mathrm{~s}, 60^{\circ} \mathrm{C}$ 加热 $1 \mathrm{~min}$, 进行 40 个循环. 溶 解曲线从 $60^{\circ} \mathrm{C}$ 上升到 $90^{\circ} \mathrm{C}$, 速度为 $0.5^{\circ} \mathrm{C} / \mathrm{s}$. 对每个试验 样品均设置 3 次重复, 以确保准确性. 以䒨著苜宿的持 家基因Actin作为内参，基因表达水平与相对量化分析 采用 $2^{-\Delta \Delta C_{\mathrm{T}} \text { 方法 }}{ }^{[15]}$, 使用SPSS 19.0软件绘图.

(V) MTR_8g079250基因时空表达分析. 通过预测 与鉴定, 确定MTR_8g079250为研究对象. 通过 $\mathrm{qRT}$ PCR技术检测MTR_8g079250在接菌和不接菌条件下 的表达差异, 取样时间为接菌后 $0 、 3 、 5 、 7 、 10 、 15$ 和 $25 \mathrm{~d}$. 对接菌后 $28 \mathrm{~d}$ 蒺藜苜宿的茎部、叶片、根瘤和 去瘤根分别取样, 提取RNA反转录获得cDNA后, 检测 该基因在教㢣苩宿不同组织中的表达情况.

(vi) MTR_8g079250基因的洋葱亚细胞定位. 使用 特异性引物扩增MTR_8g079250基因全长序列: 上游引 物为C50-F: ACTCTAGAGGATCTCGAGATGGGTCGTAAAAAGTTTG; 下游引物为 C50-: $C A T G G$ -

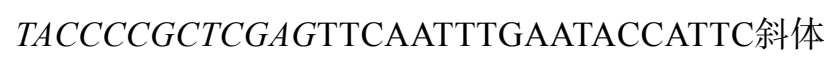
标记的核苷酸与载体同源, 下同, 在两端添加Xho I 酶 切位点. 使用ClonExpress ${ }^{\circledR}$ II 一步克隆试剂盒(Vazyme, 南京)将扩增的片段克隆到洋苾表皮亚细胞定位载体 中, 生成MTR_8g079250-GFP. MTR_8g079250-GFP在洋 葱表皮细胞中通过使用生物特性的PDS-1000/He粒子 
传递系统(Bio-Rad)进行基因枪转化法瞬时表达. 洋葱 表皮细胞用 $4 \% \mathrm{NaCl}$ 处理 $5 \mathrm{~min}, 25^{\circ} \mathrm{C}$ 避光孵育 $24 \sim 48 \mathrm{~h}$ 后立即进行显微镜观察.

(vii) MTR_8g079250烟草叶片亚细胞定位. 根据目 的基因的编码框设计上下游引物Y $50-\mathrm{F}$ (CTAGTCTA$G A$ AT G G G T C G TA A A A A G T T T G) 及 Y 50 - R (TCCCCCCGGGTTCAATTTGAATACCATTC)扩增目 的片段. 在载体 $X b a \mathrm{I}$ 和 $X m a \mathrm{I}$ 位点进行双酶切并回收 产物, 使用 $\mathrm{T} 4$ 连接酶对线性化载体和目的片段进行连 接, 构建p35S::MTR_8g079250::eGFP载体. p35S:: MTR_8g079250::eGFP通过农杆菌瞬时化法注射本塞 姆氏烟草叶片, 注射后的烟草暗培养 $24 \mathrm{~h}$ 后转人普通光 照培养箱培养 $2 \sim 5 \mathrm{~d}$, 用刀片切取约 $1 \mathrm{~cm} \times 1 \mathrm{~cm}$ 注射后的 叶片, 清水制片, 置于激光共聚焦显微镜下进行观察.

(viii) 启动子融合表达载体. 使用PromoterScan软件 对MTR_1g083380进行分析, 预测启动子序列, 使用Primer Premier 5.0软件设计引物, 包含 $M T R \_8 g 079250$ 基 因前的-2001-1序列：PR50-F, CTTGGCTGCAGGTCGACGGATATTCCGGTGACTTTAAT; PR50-R, TTAGAATTCCCGGGGATCTAATATCAATAATTGTTCCT. 提取教藜苜宿A 17 的DNA为模板, 扩增目的片段, 通过 同源重组法构建pMTR_8g079250::GUS融合表达载体, 方法同( vi). 将重组载体质粒用电转的方法转人发根农 杆菌感受态Arqua1后进行发根转化. 取接种根瘤菌后 $7 \mathrm{~d}$ 的转化植株进行GUS染色后, 用光学显微镜观察启 动子表达部位.

(ix) RNA干扰载体的构建. 使用软件Premer Premier 5.0在目的基因的 5'端和3'端各设计一组引物： RNAi-1F, 5'-GGGGACAAGTTTGTACAAAAAAGCAGGCTTCTGCGTTATGGGAATGA-3'; RNAi-1R, 5'GGGGACCACTTTGTACAAGAAAGCTGGGTGTTGGAGGAGCAAGAAGTAC-3'; RNAi-2F, 5'-GGGGACAAGTTTGTACAAAAAAGCAGGCTTTGACCTTGCAAAGAAAACT-3'; RNAi-2R, 5'-GGGGACCACTTTGTACAAGAAAGCTGGGTTCATCTCCAAGTTGTTA$\mathrm{AGC}-3^{\prime}$. $\mathrm{RNAi}-1$ 干扰片段为目的基因 CDS 的 $169 \sim 448 \mathrm{bp} ; \mathrm{RNAi}-2$ 干扰片段为目的基因 CDS的 2731 2965 bp. 分别在上下游引物的两端添加attB1和 attB2位点序列(以斜体字表示), 确保目的基因可以在 BP克隆酶的作用下与载体发生位点特异性重组：根据 Gateway BP clonase的说明书与载体进行BP克隆重组, 构建pMTR_1g083380-RNAi载体. 利用干扰载体上的
酶切位点 Xba I 和 Xho I , 使用限制性内切酶分别对重 组质粒进行单酶切验证.

（X）过表达载体构建. 按照亚细胞定位载体的构 建方法对载体p35s1301进行重组构建, 转人发根农杆 菌感受态Arqua1细胞并检测阳性克隆.

(xi ) 教著苜蕧发根转化及鉴定. 毛状根转化的具 体方法参见《教愁苜宿手册》(https://www.noble.org/ medicago-handbook/). 取接菌7 d后的转化植株, 清水冲 洗根部, 除去杂质后放置于GUS染色液中浸泡染色, $37^{\circ} \mathrm{C}$ 数小时至过夜. 在 $70 \%$ 的乙醇中进行脱色, 直到阴 性对照的相应组织呈现白颜色. 取接菌(lac Z标记) $7 \mathrm{~d}$ 后的转化植株: $0.1 \mathrm{~mol} / \mathrm{L}$ 的磷酸盐缓冲液固定 $1 \mathrm{~h}$, 缓 冲液浸泡冲洗 $15 \mathrm{~min}$, 重复两次. X-gal染色法检测 $\beta$-半 乳糖苷酶的活性, 染液浸没根部, 黑暗条件下室温过夜. 次日除去染液, 用 $0.1 \mathrm{~mol} / \mathrm{L}$ 的磷酸盐缓冲液冲洗根部 $10 \mathrm{~min}$, 重复3次; $\mathrm{ddH}_{2} \mathrm{O}$ 冲洗 $5 \mathrm{~min}$, 重复 2 次. 用 $10 \%$ 的 漂白剂浸泡植物材料 1 3 min, $\mathrm{ddH}_{2} \mathrm{O}$ 冲洗3次.

\section{2 结果}

\subsection{HMA5系统发育分析}

HMA中的 $\mathrm{P}_{1 \mathrm{~B}}$ 被证实与重金属的转运相关 ${ }^{[6,16,17]}$. 拟南芥和水稻中分别含有 8 和 9 个 $\mathrm{P}_{1 \mathrm{~B}}$-ATPase 家族成 员 ${ }^{8]}$. 双子叶模式植物拟南芥中HMA家族中的所有成 员均已进行了功能鉴定和分类. 其中AtHMA5参与 $\mathrm{Cu}$ 由根部到茎部的转运以及根部的解毒 ${ }^{[7,18]}$. 对䒨愁苜宿 中的HMA所有相关基因进行聚类分析构建系统发育 树, 确定苼著苜宿HMA5家族的相关基因. 以目前分类 明确的HMA家族基因为依据，使用软件MEGA6，用最 大似然法构建系统发育树(图1). 与各物种HMA基因进 行对比分析发现, 薮藜苜宿中的MTR_8g079250、 $M T R \_5 g 010420$ 和MTR_8g012390与其他物种的HMA5

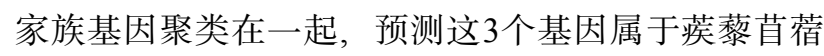
HMA5家族.

\section{2 荹藜苜宿HMA5基因表达分析}

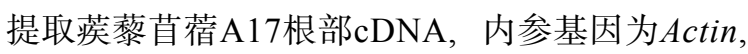
通过 q R T - P C R 检测接菌和不接菌条件下 MTR_8g079250、MTR_5g010420和MTR_8g012390在 根中的表达差异，发现 3 个基因在接种根中均受到不同 程度的诱导. 其中, MTR_8g079250主要在共生前期表 达, 在接菌后 $5 \mathrm{~d}(5 \mathrm{dpi}$, days post-inoculation)被强烈诱 


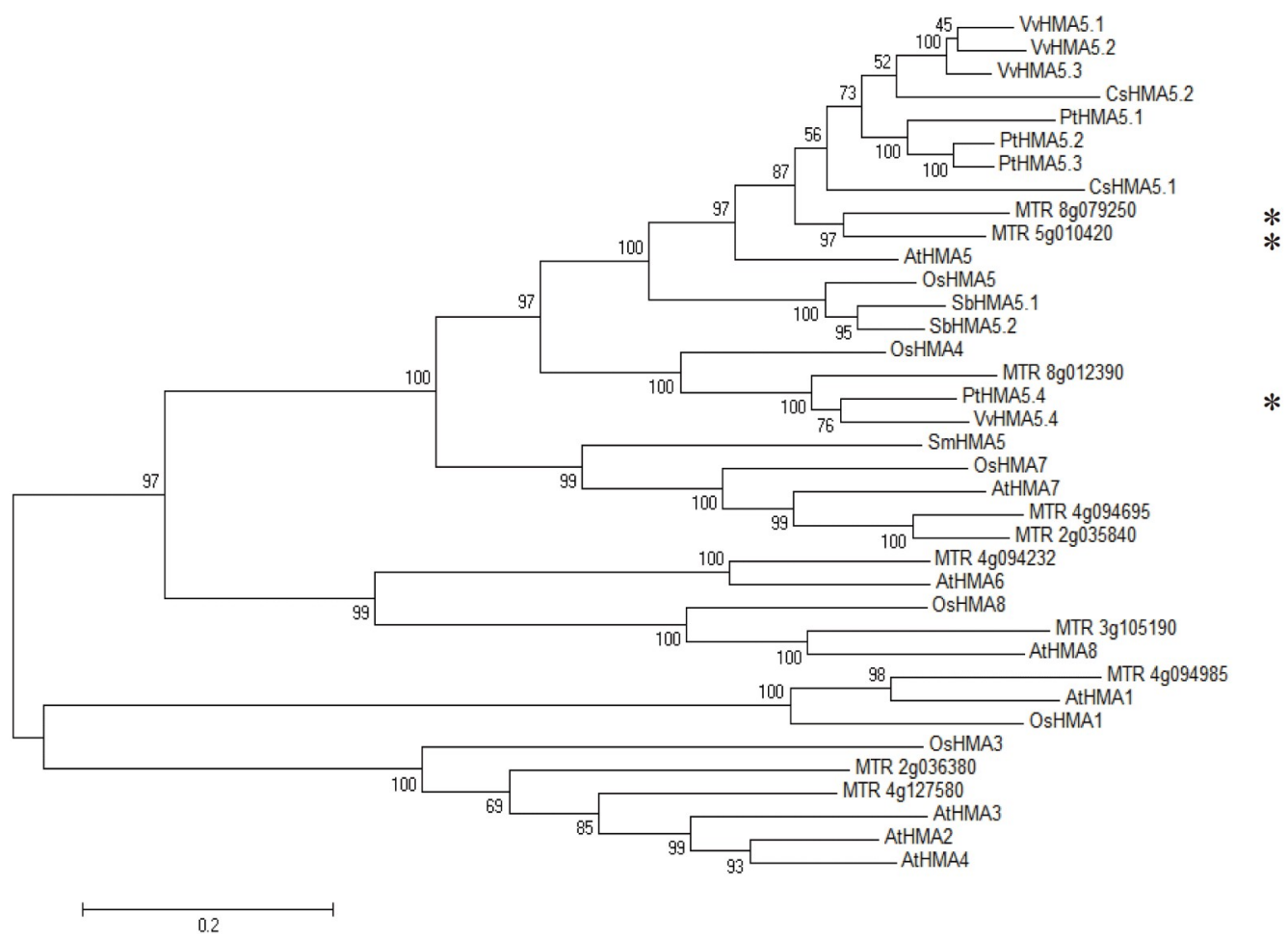

图 1 HMA5系统发育分析. *为跻㢣萛宿中的HMA5同源基因. 系统发育分析选取的物种: 拟南芥(Arabidopsis thaliana, At)、水稻(Oryza sativa, Os)、黄瓜(Cucumis sativus, Cs)、毛果杨(Populus trichocarpa, Pt)、葡萄(Vitis vinifera, Vv)、高粱(Sorghum bicolor, Sb)、卷柏(Lycophyte selaginella, Ls)

Figure 1 Phylogenetic analysis of HMA5. * is the homologous gene of HMA5 in Medicago truncatula. Species selected for phylogenetic analysis: Arabidopsis thaliana (At), Oryza sativa (Os), Cucumis sativus (Cs), Populus trichocarpa (Pt), Vitis vinifera (Vv), Sorghum bicolor (Sb), and Lycophyte selaginella (Ls)

导(图2(a)); MTR_5g010420在整个共生过程中都受到接 种根瘤菌的显著诱导, 在 $28 \mathrm{dpi}$ 表达量最高(图2(b)); MTR_8g012390在共生中期和后期表达量较高, 在28 dpi受到强烈诱导, 但其他检测时期与未接种对照相比 没有太大差异 (图 2(c)). MTR_5g010420和 $M T R \_8 g 079250$ 接菌后的表达量上调明显, 推测其与共 生关系更为密切.

根据前期实验所知, 低浓度 $\mathrm{Cu}^{2+}(50 \mathrm{mg} / \mathrm{kg})$ 促进苜 宿的生长和共生结瘤、高浓度 $\mathrm{Cu}^{2+}(200 \mathrm{mg} / \mathrm{kg})$ 抑制植 株的生长与根瘤形成, 因此选取这两个浓度对蔳藜苜 宿进行处理. qRT-PCR检测不同 $\mathrm{Cu}^{2+}$ 浓度处理下教溗苜 宿根中MTR_8g079250、MTR_5g010420和 $M T R \_8 g 012390$ 的表达情况. 在加铜时, MTR_ $8 g 079250$ 在 5 和 $10 \mathrm{dpi}$ 的表达均下调, 但在 $200 \mathrm{mg} / \mathrm{kg}$ 铜胁迫时, MTR_8g079250在结瘤后期表达上调(图2(d)); 无论低 浓度还是高浓度铜处理, MTR_5g010420表达均下调 (图2(e)); 低浓度铜处理时, MTR_8g012390的表达与对
照相比没有明显区别，高浓度铜处理 时， MTR_8g012390表达在10及 $28 \mathrm{dpi}$ 下调, 在 $23 \mathrm{dpi}$ 有所上 调(图2(f)). 这说明, 在静藜苜宿共生结瘤过程中, 3 个基 因在对不同浓度铜离子的响应中可能发挥着不同作用, 其中 MTR_8g079250可能和长期(结瘤后期)过量铜胁迫 相关. 结合与共生的关系, 选定MTR_8g079250为研究 的目的基因.

\subsection{MTR_8g079250基因的亚细胞定位}

在CaMV35S启动子的控制下表达绿色荧光蛋白 (GFP)标记的MTR_8g079250. 通过基因枪转化法将质粒 转人洋葱表皮细胞. GFP空载体作为对照. 在表达GFP标 记的MTR_8g079250的细胞中, 绿色苂光主要出现在细 胞膜和细胞核上(图3(a)); 在表达GFP::MTR_8g079250 的本氏烟草叶片中也发现了类似的结果(图3(b)), 说明 目的基因 $M T R \_8 g 079250$ 主要定位于细胞膜和细胞核, 其作用可能与物质的转运及信号传递相关. 

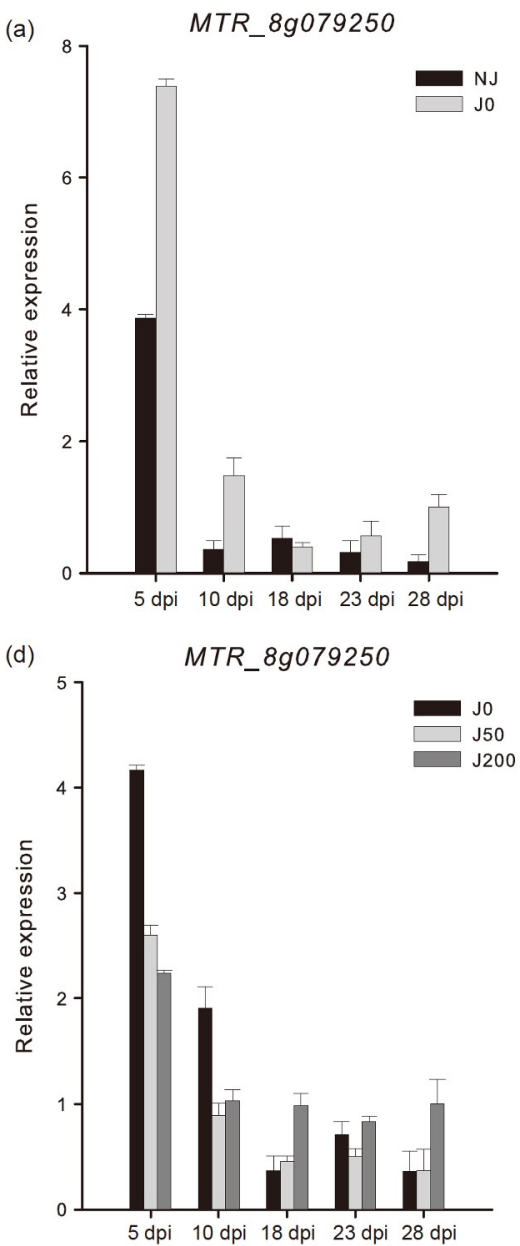
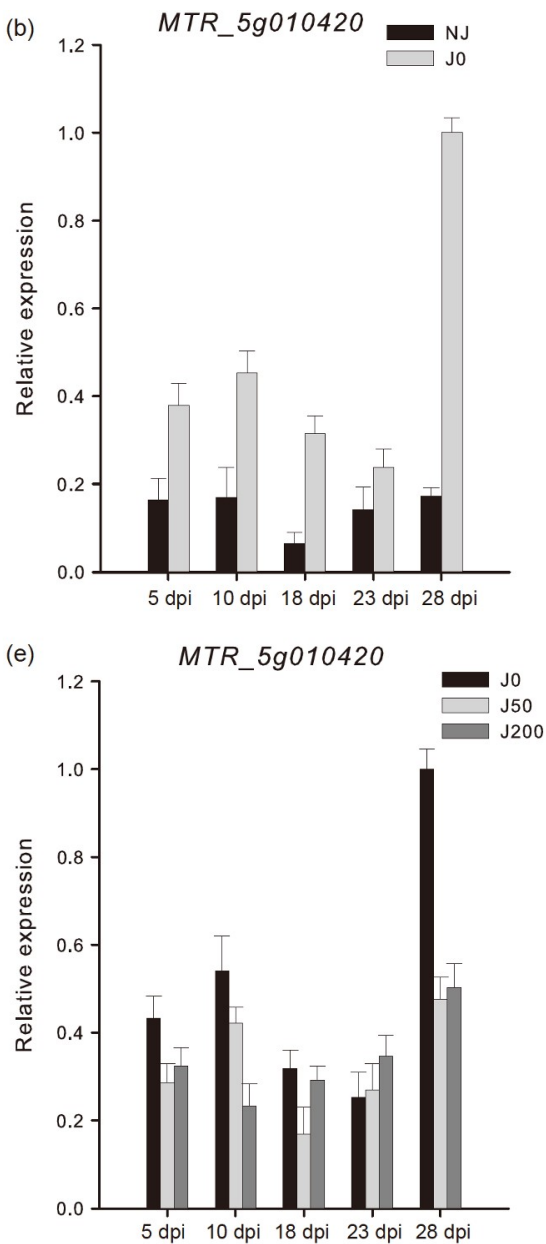
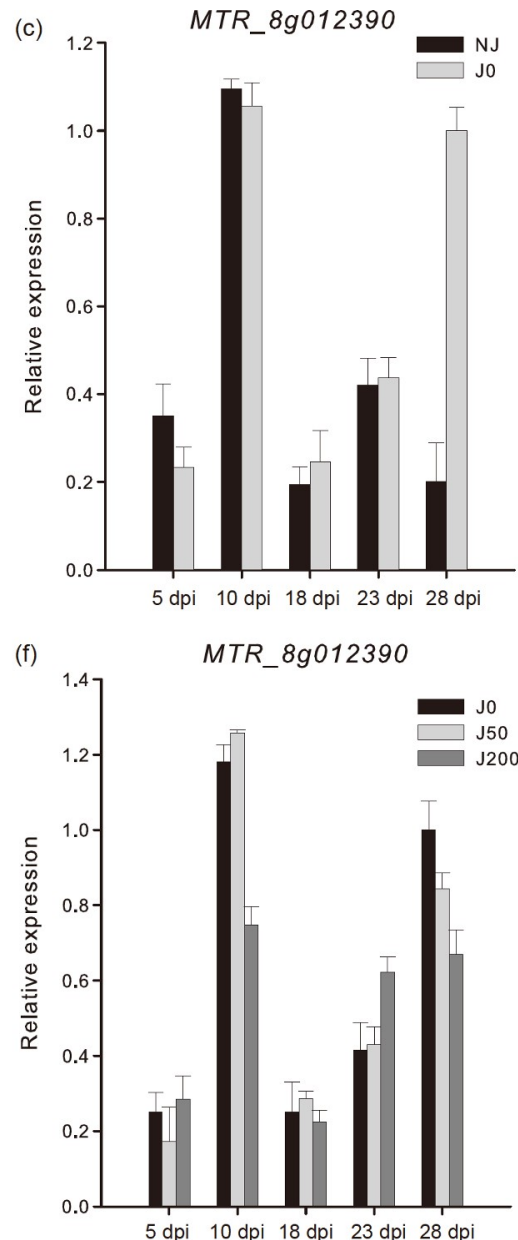

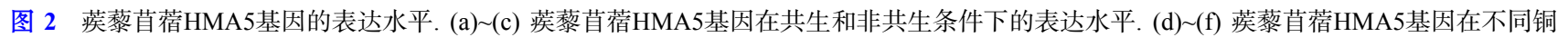
浓度下的表达水平. NJ为不接种根瘤菌处理, J0为接种根瘤菌不加铜处理, $\mathrm{J} 50$ 为接种根瘤菌加 $50 \mathrm{mg} / \mathrm{kg}$ 铜处理, $\mathrm{J} 200$ 为接种根瘤菌加 $200 \mathrm{mg} / \mathrm{kg}$ 铜处理

Figure 2 The Medicago truncatula HMA5 gene expression level. (a)-(c) The expression level of HMA5 gene in Medicago truncatula under symbiotic and non-symbiotic conditions. (d)-(f) The expression level of HMA5 gene in Medicago truncatula under different Cu concentrations. NJ means no inoculation of rhizobia, J0 means inoculation of rhizobia without Cu treatment, J50 means inoculation of rhizobia with $50 \mathrm{mg} / \mathrm{kg} \mathrm{Cu}$ treatment, and J200 means inoculation of rhizobia with $200 \mathrm{mg} / \mathrm{kg} \mathrm{Cu}$ treatment

\subsection{MTR_8g079250的组织表达}

用MTR_8g079250的自身启动子连接GUS报告基 因, 构建融合表达载体, 通过发根转化法转人荹著苜宿 根部, 取接种根瘤菌后 $28 \mathrm{~d}$ 的转化植株根及根瘤染色观 察，在整个根瘤原基、成熟根瘤的顶端分生区、侵染 区及外围皮层组织中可见蓝色. 观察侧根根尖、主根 根尖以及根成熟区等部位，发现根的中柱和根冠被染 成蓝色(图4). 因此推测 $M T R \_8 g 079250$ 参与根部铜离子 在维管组织以及新生组织中的转运.

\subsection{MTR_8g079250在共生中的功能分析}

为了研究MTR_ $8 g 079250$ 在共生结瘤中的作用, 采
用RNAi抑制其表达，构建RNA干扰重组质粒电转人发 根农杆菌Arqua1, 发根转化静藜苜宿. 检测GUS基因在 转化植株根部的表达, 验证转化成功. RT-PCR和qRTPCR检测, 结果与对照相比，干扰植株根部目的基因 的表达量下调 $40 \%$ (图S1).

将转化植株转人珍珠岩和蛭石的混合培养基中培 养3 d 后接种lac Z标记的根瘤菌, $7 \mathrm{~d}$ 后染色观察, 分析 侵染情况(图5). 与对照组相比, 干扰植株的根毛卷曲及 侵染线没有差异，皮层侵染线和根瘤原基稍有增多. 观 察接菌后 $28 \mathrm{~d}$ 的转化植株, 发现RNAi-1植株与对照相 比无明显差异，RNAi-2植株侧根较多，根瘤较多且略 有增大，颜色更深．RNAi-1在株高、根长、鲜重及根 


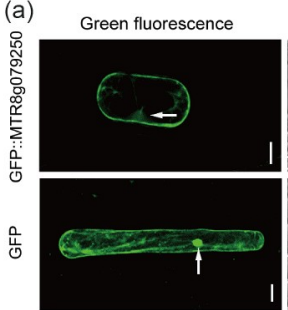

(b) Green fluorescence
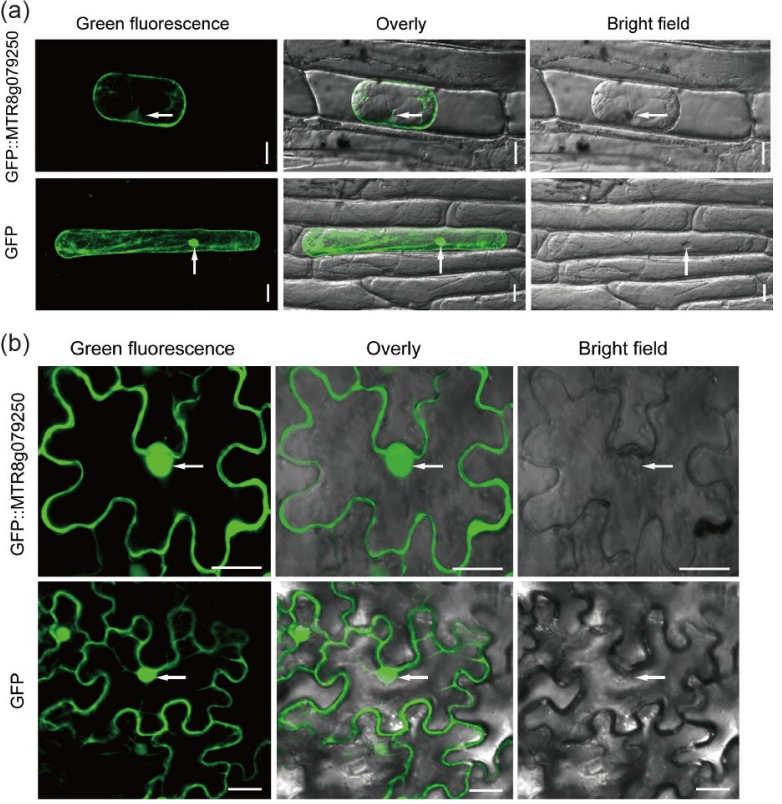

Bright field

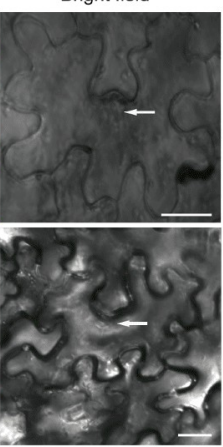

图 3 (网络版彩色)GFP::MTR_8g079250融合蛋白的亚细胞定位. (a) GFP::MTR_8g079250融合蛋白在洋葱表皮细胞中的亚细胞定位, GFP空载体作对照, 标尺为50 $\mu \mathrm{m}$. (b) GFP::MTR_8g079250融合蛋白 在烟草叶片细胞中的亚细胞定位, GFP空载体作对照, 标尺为 $50 \mu \mathrm{m}$ 箭头所指处为细胞核

Figure 3 (Color online) Subcellular localization of the GFP:: MTR_8g079250. (a) Subcellular localization of GFP::MTR_8G079250 in onion epidermal cells. GFP empty vector is as control with a scale of $50 \mu \mathrm{m}$. (b) Subcellular localization of GFP::MTR_8G079250 in tobacco leaf cells. GFP empty vector is as control with a scale of $50 \mu \mathrm{m}$. The arrow points to the nucleus

瘤数目等方面无明显差异; RNAi-2虽在鲜重和根瘤数 目上有所增加, 但差异均不显著(图S2).

接菌 $28 \mathrm{~d}$ 后观察根瘤的超微结构, 结果显示, RNA 干扰转化植株的根瘤侵染细胞中类菌体与对照植株相 比无明显差异(图S3). qRT-PCR检测RNA干扰转化植株 根部的基因表达量，发现 $N I N$ 表达量上升; 接菌 $5 \mathrm{~d}$ 后， $E N O D 11$ 的表达量有所上升(图S4(a)).

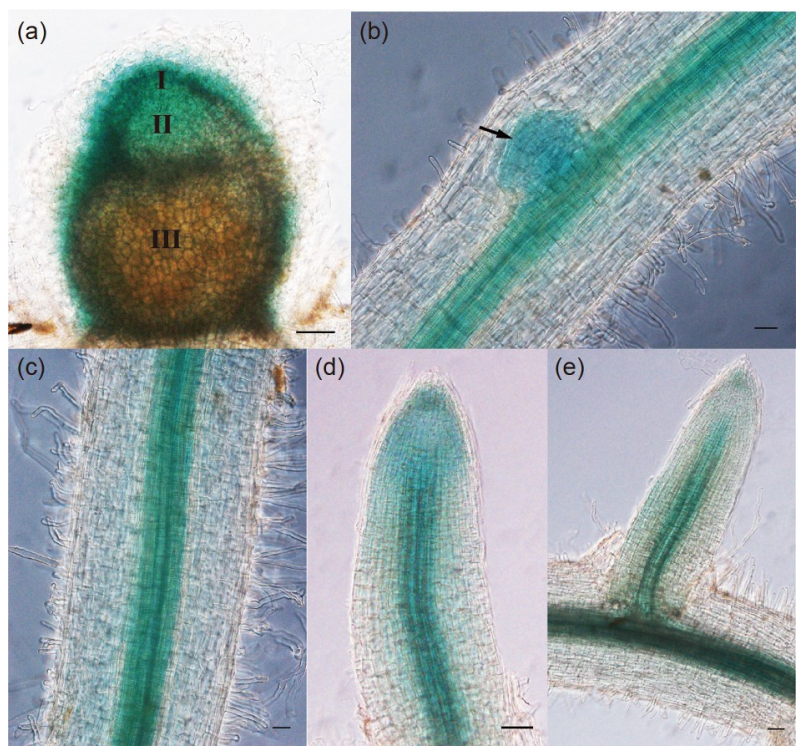

图 4 (网络版彩色)pMTR_8g079250::GUS融合蛋白在蔟著苜宿根 及根瘤中的表达. (a)，(b) pMTR_8g079250::GUS在根瘤和根瘤原基 中的表达, I、II、III分别表示顶端分生组织、侵染区、固氮区, 箭 头指示根瘤原基. (c) pMTR_8g079250::GUS在根成熟区的表达. (d), (e) pMTR_8g079250::GUS在主根根尖和侧根根尖中的表达. 标尺为 $200 \mu \mathrm{m}$

Figure 4 (Color online) Expression of pMTR_8G079250::GUS in roots and nodules of Medicago truncatula. (a), (b) Expression of pMTR 8G079250::GUS in nodules and nodule primordial. I is the apical meristem, II is infection zone, and III is nitrogen fixation zone. The arrows indicate the nodule primordia. (c) pMTR_8g079250::GUS expression in the root maturation zone. (d), (e) pMTR_8G079250::GUS expression in the root tips of principal root and lateral roots. Scale is $200 \mu \mathrm{m}$

$M T R \_5 g 010420$ 和 MTR_8g012390是MTR $8 g 079250$ 的同源基因. 对干扰植株中这两个同源基因 的表达量进行检测发现，在干扰转化根中， MTR_8g012390表达均上调，MTR_5g010420略有上调 或下调(图S4(c)).

已有研究表明，拟南芥乙烯信号传导通路中所必 需的铜离子由ATX1转运给HMA7/RAN1, 同时, 两个
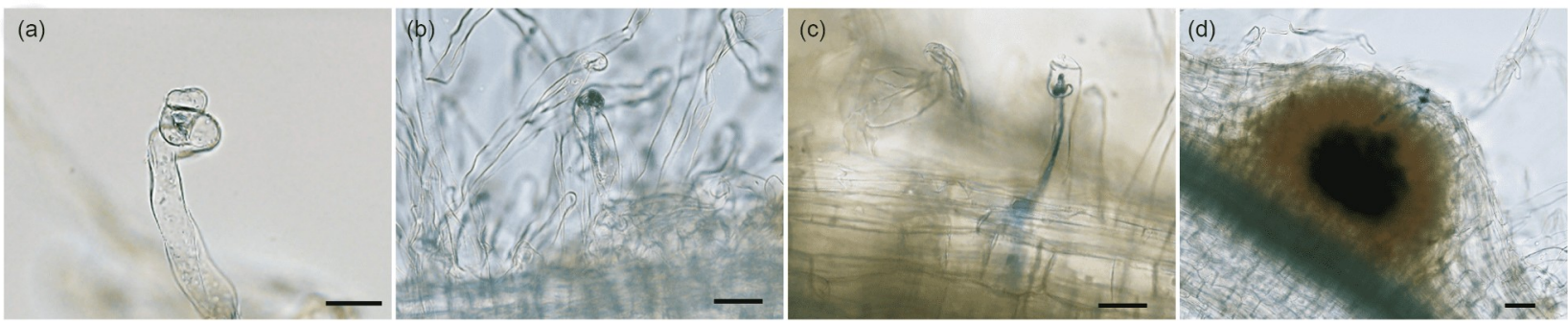

图 5 (网络版彩色)接种根瘤菌7 d后MTR_8g079250 RNAi与过表达转化植株中的侵染事件观察. (a) 根毛卷曲; (b) 根毛侵染线; (c) 皮层侵染线; (d) 根瘤原基. 标尺为 $100 \mu \mathrm{m}$

Figure 5 (Color online) Infection events of MTR_8g079250 RNAi and overexpressed transgenic plants at 7 dpi. Root hair curling (a), infection threads (ITs) in root hair (b) or in the cortex (c), and nodule primordia (d). Scale is $100 \mu \mathrm{m}$ 

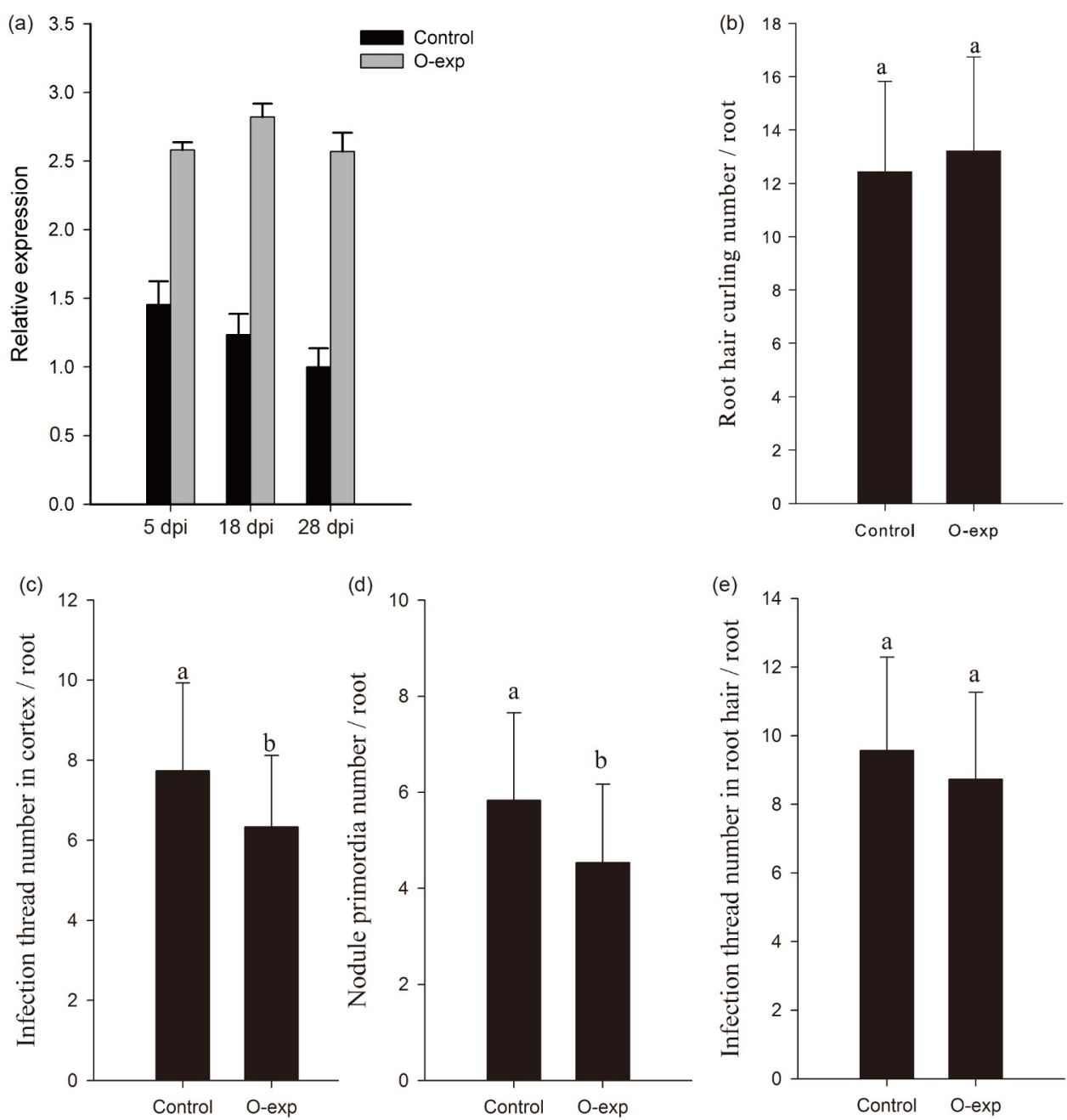

图 6 MTR_8g079250在过量表达植株中的表达. (a) qRT-PCR分析MTR_8g079250在接菌后5、18和28 d的教葱苜宿转化根中的表达水平, 以蒺 藜苜宿的Actin rDNA的表达水平进行标准化, 误差棒显示为标准误, 设置 3 个重复. (b) (e) 接菌 $28 \mathrm{~d}$ 后的过量表达转化植株侵染事件统计: (b) 根 毛卷曲; (c) 皮层侵染线; (d) 根瘤原基; (e) 根毛侵染线. 数值表示平均值, 误差棒显示为标准差, 样本容量为 30 株植物, $t$ 检验, $P<0.05$, 不同的字母 表示具有显著性差异

Figure 6 Infection events of MTR_8G079250 expressioned transgenic plants. (a) qRT-PCR analysis of the expression levels of $M T R \_8 g 079250$ in 5, 18 and 28 dpi transformed roots, with Actin rDNA in Medicago truncatula as the endogenous control. Data are presented as the mean \pm SE, with three replicates. Numbers of root hair curlings (b), ITs in root hair (e) or in cortex (c) and nodule primordial (d) per root of the control and MTR_8G079250overexpressioned plants. The data were collected from 30 independent hairy root systems in each group of plants. Data are presented as the mean $\pm \mathrm{E}$. Different letters above the bars indicate significant differences $(P<0.05$, Student- $t$ test $)$

铜离子伴侣蛋白ATX1和CCH分别与HMA5互作 ${ }^{[19]}$. 因 此推测，在植物中铜离子是由HMA5经ATX1和CCH传 递给HMA7/RAN1，最终将铜离子转运给乙烯受体. 通 过比对和预测, MTR_4g094695和MTR_2g035840与 HMA7/RAN1家族的相似性最高，铜离子伴侣MTR$1 g 092670$ 与 $\mathrm{CCH}$ 相似度最高. qRT-PCR检测了苼藜苜 宿RNA干扰植株中铜离子伴侣和HMA7/RAN1基因的 表达情况. 在干扰植株中 $M T R \_4 g 094695$ 、 MTR_2g035840和MTR_1g092670的表达量均无明显变
化(图S4(b)).

在MTR_8g079250的干扰实验中, 通过观察侵染事 件和根瘤超微结构发现，与对照相比，差异不明显，因 此推测可能存在基因的功能圥余. 为更进一步探究 MTR_8g079250在共生结瘤进程中的功能, 对其进行了 过量表达.

构建过表达重组质粒电转人发根农杆菌感受态 Arqua1, 转化薮㢣苜宿. RT-PCR显示, 转化植株根部目 的基因表达量上调一倍多. 根毛卷曲数目与对照组无 

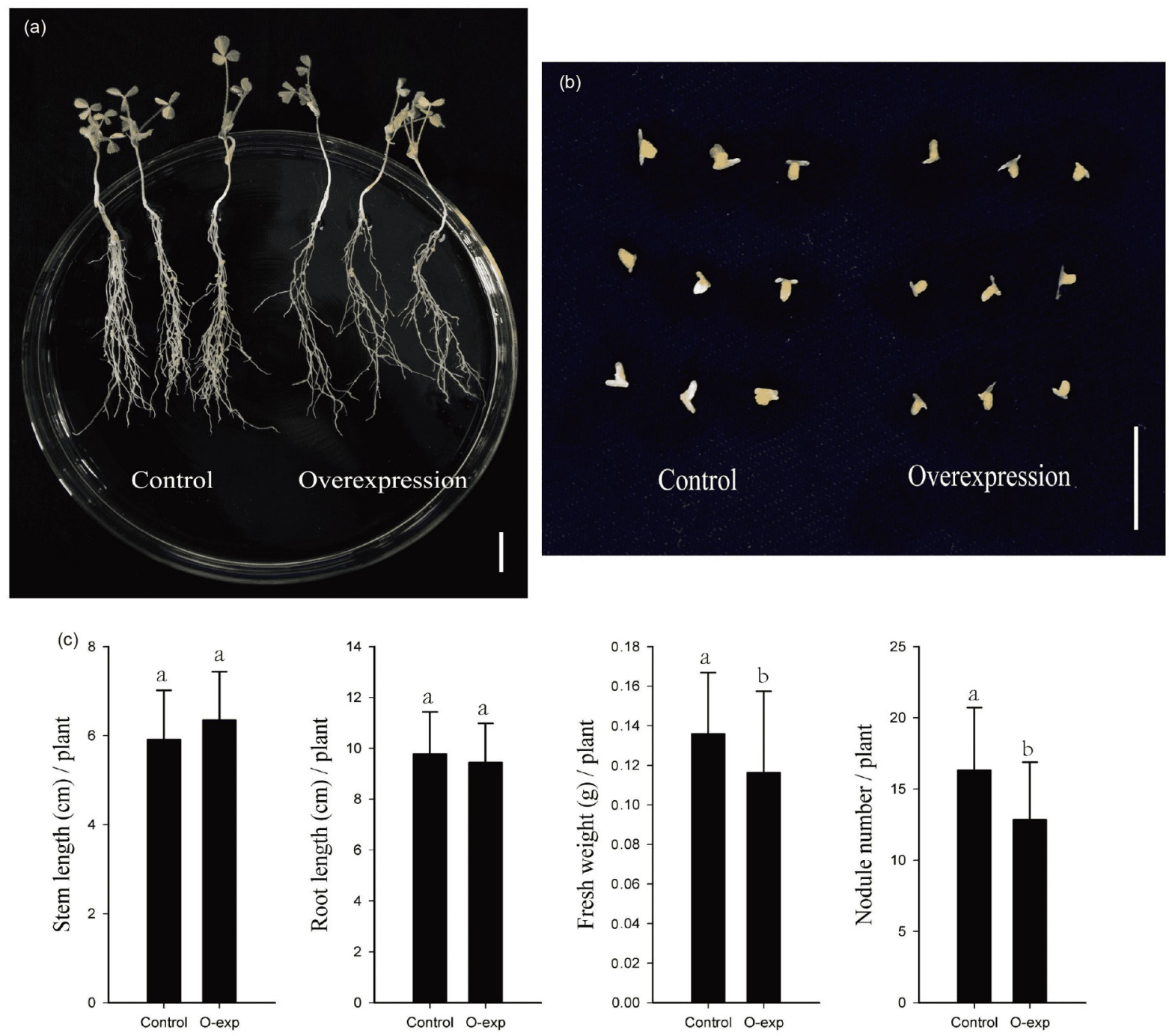

图 7 (网络版彩色)接种根瘤菌 $28 \mathrm{~d}$ 后过量表达MTR_8g079250转化植株的生长表型及生理指标统计. (a) 转化植株表型. 标尺为 $1 \mathrm{~cm}$. (b) 转化植 株根瘤表型, 标尺为 $1 \mathrm{~cm}$. (c) 转化植株的生理指标统计: 依次为株高、根长、鲜重、根瘤数. 误差棒显示为标准差, 样本容量为 30 株植物, 不同 的字母表示具有显著性差异, $t$ 检验, $P<0.05$

Figure 7 (Color online) MTR $8 g 079250$-overexpressing (O-exp) transgenic plant growth phenotypes and nodulation after inoculation at 28 dpi. (a) Transgenic plants. Scale bar $=1 \mathrm{~cm}$. (b) Nodules phenotypes. Scale bar $=1 \mathrm{~cm}$. (c) The lengths of stems and roots, fresh weight and number of nodules were scored at $28 \mathrm{dpi}$. The numbers of independent hairy root systems scored are 30 for each construct. Data are presented as the mean $\pm \mathrm{E}$. a and $\mathrm{b}$ above the bars indicate significant differences $(P<0.05$, Student- $t$ test $)$

差异，根毛侵染线、皮层侵染线和根瘤原基的数目均 有所减少，其中皮层侵染线和根瘤原基的数目显著减 少(图6)。过表达植株叶片发黄，侧根稀疏，根瘤较小， 根瘤数目与植株鲜重明显减少(图7). 透射电子显微镜 观察根瘤超微结构发现，对照根瘤中被侵染的细胞中 类菌体排列紧密, 数目较多, 形状规则. 而过量表达转 化植株的根瘤受侵染细胞中类菌体稀疏, 数目较少, 环 类菌体空间明显扩大，甚至出现类菌体被降解后的空 胞, 说明根瘤开始衰老(图8).
qRT-PCR检测根中相关基因，发现在接菌后不同 时期，与根瘤形成相关基因的表达均有不同程度的下 降, 这与根瘤数减少的现象一致; 与成熟根瘤固氮功能 相关的豆血红蛋白的表达量也有所下调(图9(a)).

对 MTR_8g079250的同源基因MTR_5g010420和 MTR_8g012390进行检测发现，过表达植株中， MTR_5g010420表达量略有上调，MTR_8g012390略有 下调(图9(c)), 推测MTR_8g079250过量表达不会引起 另外两个同源基因的转录变化, 即使有, 影响也较小. 

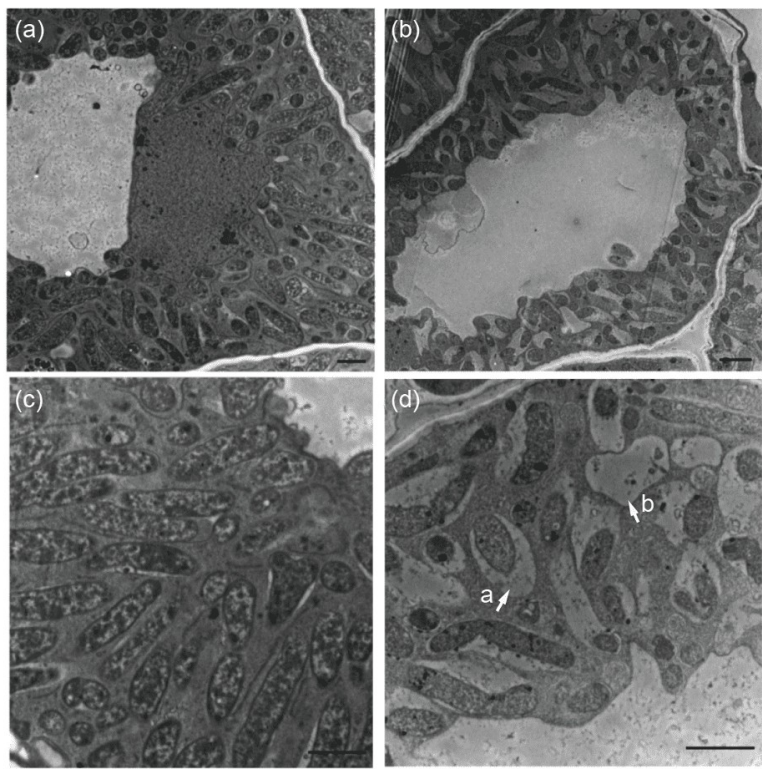

图 8 过量表达转化植株根瘤透射电子显微镜观察. (a), (c) 空载体 对照; (b), (d) 过量表达. 箭头所示 $a$ 为环类菌体空间增大, $b$ 为空胞, 标 尺为 $2 \mu \mathrm{m}$

Figure 8 TEM micrographs of MTR 8g079250-overexpressing nodules at 28 dpi. (a), (c) Control; (b), (d) Rpf84-overexpressing plants. Arrow a shows the space increase of the cycloids, and arrow b shows empty cell. Scale bars $=2 \mu \mathrm{m}$

对HMA7/RAN1的同源基因和 $\mathrm{CCH}$ 的同源基因进 行表达检测发现，过表达植株中MTR_4g094695及CCH 同源基因的表达无明显变化; MTR_2g035840表达量上 调一倍以上(图9(b)). 这说明 $M T R \_8 g 079250$ 基因过量表 达可能诱导了MTR_2g035840基因的表达，推测飺藜苜 蕧中HMA5家族基因与HMA7/RAN1家族基因在功能 上有一定的相关性.

\section{3 讨论}

水稻中的 9 个HMA家族成员中有 5 个已经得到了较 为详细的研究. 其中, OsHMA5定位在质膜上, 参与将 铜转运到根和其他器官的木质部 ${ }^{[20]}$. 双子叶模式植物 拟南芥中HMA家族中的所有成员均已进行了功能鉴 定和分类. AtHMA5被发现参与 $\mathrm{Cu}$ 由根部到茎部的转 运以及根部的解毒 ${ }^{[12,18]}$. 在黄瓜基因组中鉴定出了 8 个 假定的 HMA 家族成员 ${ }^{[21]}$ 。其中，CsHMA5.1 和 CsHMA5.2 是对铜高度亲和的转运体，定位在液泡膜 上, CsHMA5.2可以将 $\mathrm{Cu}$ 隔离在液泡中从而行使解毒 功能 ${ }^{[22]}$.

近年来，对豆科植物HMA5基因的研究鲜见报道. 本研究主要对豆科模式植物薮藜苜宿中HMA5基因的
同源基因 $M T R \_8 g 079250$ 在根瘤形成过程中的功能进 行了初步探索. 表达分析显示, 在铜胁迫时, 接菌 $18 \mathrm{~d}$ 后MTR_8g079250的表达量上升,在接菌 $28 \mathrm{~d}$ 时上调明 显. 已有研究表明, 拟南芥和黄瓜中的HMA5都具有解 毒功能, 因此可以推测在飺藜苜宿中过量铜处理时, 结瘤后期MTR $8 g 079250$ 的表达上调可能也与解毒 有关.

对水稻和黄瓜中的HMA5基因表达分析显示， OsHMA5主要在根维管束细胞和节间弥散性维管束的 木质部区域以及花序梗、轴和壳的维管束组织中表达, 定位在质膜上 ${ }^{[20] ;}$ 黄瓜CsHMA5.1和CsHMA5.2均定位 在液泡膜上，CsHMA5.1只在根部表达，CsHMA5.2则 在根、下胚轴、子叶、叶柄和叶片等组织中均有表 达 $^{[22]}$. 拟南芥AtHMA5主要在根和花中表达, 但在细胞 和组织中的具体表达部位尚不明确 ${ }^{[12,18]}$. 类似地, 本研 究对MTR_8g079250进行组织定位检测, 发现其主要在 根的维管组织及根瘤分生区、侵染区和外围皮层组织 中表达，另外在新生根瘤原基中也有表达. 然而，亚细 胞定位显示，MTR_8g079250除了定位于质膜外，在细 胞核中也有表达. 这与水稻和黄瓜中HMA5同源基因的 定位情况有所不同, 表明在不同植物中HMA5可能具有 不同的表达模式, 行使着不同的功能.

对MTR_8g079250进行RNA干扰和过量表达研究， 以此探究它们在蒺藜苜宿与根瘤菌共生固氮中的功能. 结果发现, MTR_8g079250的RNA干扰植株与对照植株 相比，在根瘤菌侵染过程、生理表型、根瘤显微结构 和相关基因表达方面没有显著差异，说明干扰 $M T R \& 8 g 079250$ 对根瘤菌共生固氮没有明显影响. 前文 所说薮藜苜宿有 3 个 HMA 5 同源基因: $M T R$ 8g079250、MTR 5g010420和MTR 8g012390, 推测3个 基因的功能存在冗余，在干扰 $M T R \_8 g 079250$ 后，其他 两个同源基因的功能对其起到弥补作用; 同时, 也不排 除MTR_8g079250对共生过程的影响可能是间接的. 过 表达MTR_8g079250的植株与对照组相比，皮层侵染 线、根瘤原基及根瘤的数量明显减少，结瘤标志性基 因DMI1、NIN、ENOD11和豆血红蛋白都发生了不同 水平的下调, 说明 $M T R \_8 g 079250$ 的过量表达抑制了根 瘤菌的侵染过程及根瘤发育. 同时, 透射电子显微镜观 察结果显示，过表达根瘤内侵染细胞的类菌体呈现降 解的状态，预示根瘤早衰，这些都说明过表达 MTR_8g079250对结瘤有抑制作用. 接种 $28 \mathrm{~d}$ 后过表达 植株的叶片泛黄，侧根减少，鲜重下降，推测目的基因 
(a)
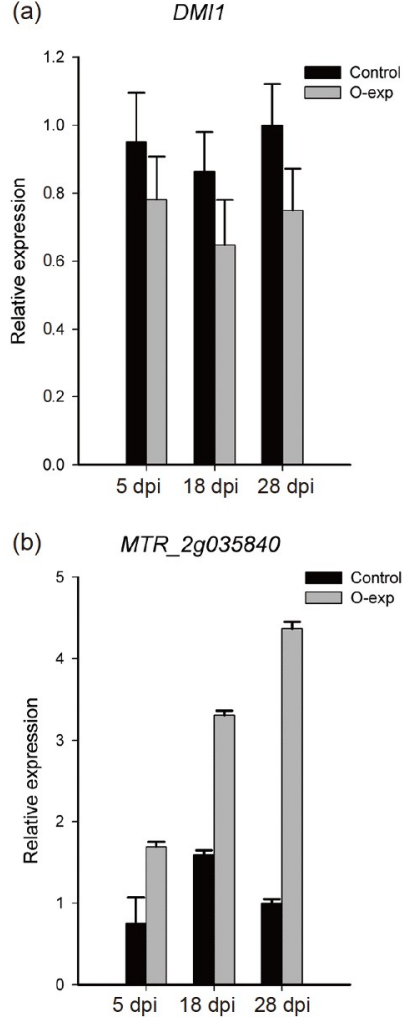

(c) MTR_5g010420

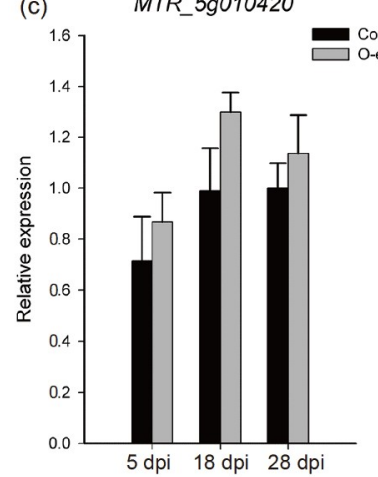

NIN
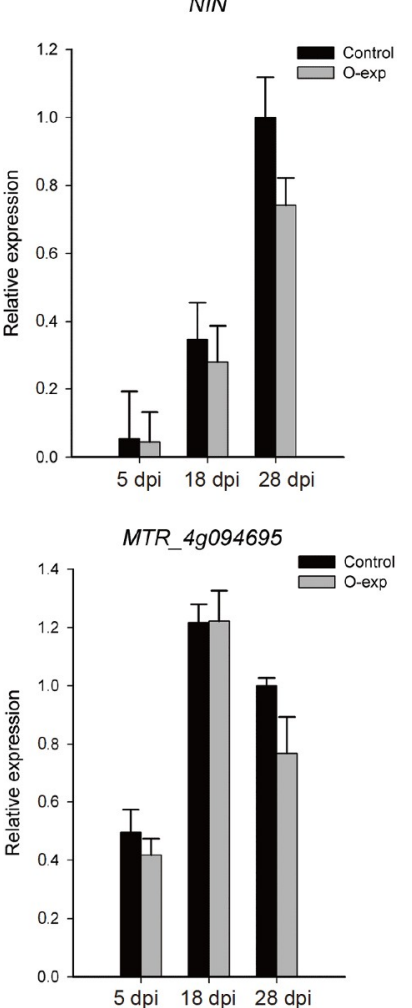

MTR_8g012390

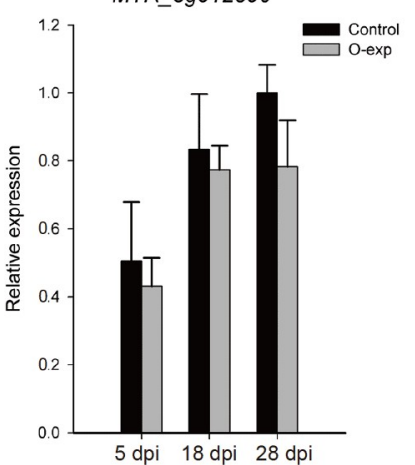

ENOD11

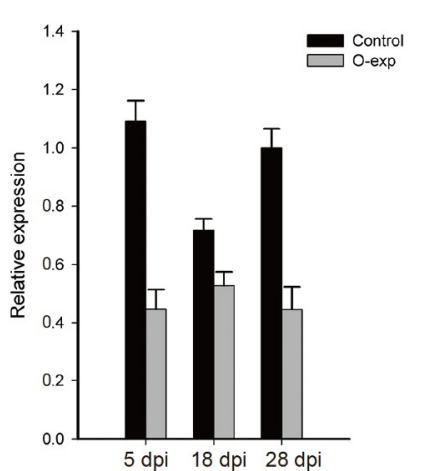

$\mathrm{CCH}$

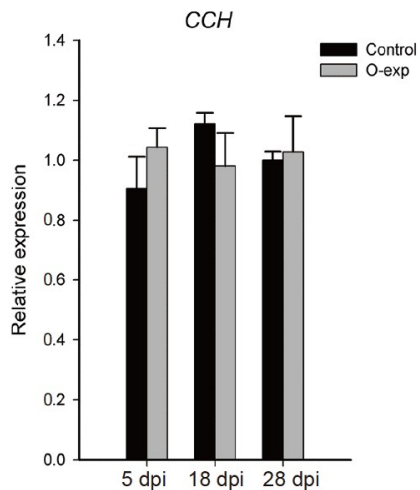

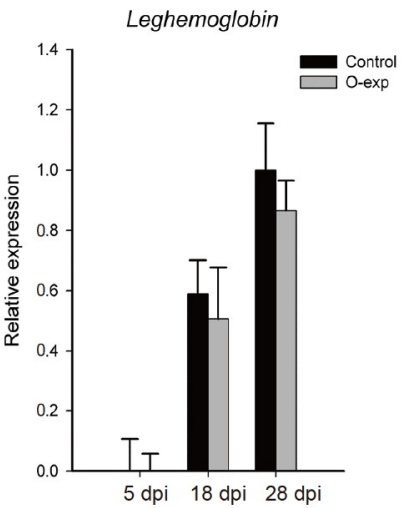

图 9 定量PCR分析MTR_8g079250过量表达转化植株中结瘤和铜转运相关基因的表达. (a) 结瘤相关基因的定量分析. (b) HMA7/RAN1同源基 因和CCH同源基因的定量分析. (c) HMA5同源基因的定量分析. 以Actin的表达量进行标准化. 误差棒显示标准误, 设置3个重复

Figure 9 qPCR analysis of the expression levels of genes related to nodulation and Cu transport in the MTR_8G079250-overexpressed transgenic plants. (a) Quantitative analysis of nodule-related genes. (b) Quantitative analysis of HMA7/RAN1 homologues genes and CCH homologues genes. (c) Quantitative analysis of HMA5 homologous genes, standardized by Actin expression. Data are presented as the mean \pm SE

过量表达后可能影响了植物自身铜离子的内稳态，从 而影响了植株的正常生长.

已有研究表明，乙烯调控根毛对结瘤因子响应的 敏感性 ${ }^{[23]}$; 干扰钙信号, 调节着表皮侵染线进入皮层的 数量 ${ }^{[24]}$; 同时, 与根瘤的起始定位有关 ${ }^{[25,26]}$. 在拟南芥 中, 乙烯首先被乙烯受体识别, 乙烯受体蛋白需要与铜 离子结合后才能发挥作用. 而铜离子具有激发子活性, 能够激活乙烯合成关键基因 $\mathrm{ACS}$ 表达，增强拟南芥的
抗病性 ${ }^{[27]}$, 是乙烯信号传导所必需的. 拟南芥AtHMA7 能够将 $\mathrm{Cu}$ 转运给乙烯受体并且参与维持幼苗中的 $\mathrm{Cu}$ 稳态 ${ }^{[28 \sim 30]}$. 而乙烯又可以通过调节结瘤因子的信号传 导来调控共生结瘤. 铜分子伴侣CCH和ATX1蛋白都可 以与HMA5的N端互作 ${ }^{[31]}$. ATX1可以将铜离子运输到 HMA7/RAN ${ }^{[19]}$ ，因此我们推测，植物中HMA5先将铜 离子传递给ATX1和 $\mathrm{CCH}$, 再传递给HMA7/RAN1, 最后 转运到乙烯受体. MTR_8g079250过表达的苼藜苜宿共 
生根中，HMA7/RAN1基因MTR_2g035840表达水平明

显上调, 说明 $M T R \_8 g 079250$ 可能通过影响细胞中与铜 离子相关的乙烯信号通路参与共生结瘤的调控. 另外, 由于铜离子是众多共生结瘤过程相关酶的辅因子,
MTR_8g079250也有可能直接影响了这些酶的活性，进 而调控共生结瘤. 目前, 没有直接的证据表明苼㢣苜宿 HMA5对共生结瘤的影响与乙烯信号通路有关. 这些问 题还有待进一步探索.

\section{参考文献}

1 Johnston A W, Yeoman K H, Wexler M. Metals and the rhizobial-legume symbiosis-Uptake, utilization and signalling. Adv Microb Physiol, 2001, 45: 113-156

2 Saito Y. Compatibility of mixed seedings of tropical legumes and grasses on a south american tropical savanna. Jarq-Jpn Agric Res Q, 2004, 38: $61-67$

3 Górskaczekaj M, Borucki W. A correlative study of hydrogen peroxide accumulation after mercury or copper treatment observed in root nodules of Medicago truncatula under light, confocal and electron microscopy. Micron, 2013, 53: 24-32

4 Rees E M, Thiele D J. From aging to virulence: Forging connections through the study of copper homeostasis in eukaryotic microorganisms. Curr Opin Microbiol, 2004, 7: 175-184

5 Chen D. Identification of biomarkers and copper binding proteins in Tilapia and Zebrafish by Proteomics Approaches. Doctor Dissertation. Hong Kong: The Chinese University of Hong Kong (Hong Kong), 2010

6 Argüello J M, Eren E, González-Guerrero M. The structure and function of heavy metal transport P1B-ATPases. Biometals, 2007, 20: 233

7 Andrés-Colás N, Sancenón V, Rodríguez-Navarro S, et al. The Arabidopsis heavy metal P-type ATPase HMA5 interacts with metallochaperones and functions in copper detoxification of roots. Plant J, 2006, 45: 225-236

8 Williams L E, Mills R F. P1B-ATPases_An ancient family of transition metal pumps with diverse functions in plants. Trends Plant Sci, 2005, 10: 491-502

9 Kim Y Y, Choi H, Segami S, et al. AtHMA1 contributes to the detoxification of excess Zn(II) in Arabidopsis. Plant J Cell Mol Biol, 2010, 58: 737753

10 Moreno I, Norambuena L, Maturana D, et al. AtHMA1 is a thapsigargin-sensitive $\mathrm{Ca}^{2+}$ /heavy metal pump. J Biol Chem, 2008, 283: $9633-9641$

11 Seigneurin-Berny D, Gravot A, Auroy P, et al. HMA1, a new Cu-ATPase of the chloroplast envelope, is essential for growth under adverse light conditions. J Biol Chem, 2006, 281: 2882-2892

12 Zhang Y, Chen K, Zhao F J, et al. OsATX1 interacts with heavy metal P1B-type ATPases and affects copper transport and distribution. Plant Physiol, 2018, 178: 329-344

13 Huang X Y, Deng F, Yamaji N, et al. A heavy metal P-type ATPase OsHMA4 prevents copper accumulation in rice grain. Nat Commun, 2016, 7: 12138

14 Migocka M, Papierniak A, Maciaszczyk-Dziubinska E, et al. Molecular and biochemical properties of two P $_{1 \mathrm{~B} 2}$-ATPases, CsHMA3 and CsHMA4, from cucumber. Plant Cell Environ, 2015, 38: 1127-1141

15 Livak K J, Schmittgen T D. Analysis of relative gene expression data using real-time quantitative PCR and the $2^{-\Delta \Delta C_{\mathrm{T}}}$ method. Methods, 2001, 25: $402-408$

16 Burkhead J L, Reynolds K A G, Abdel-Ghany S E, et al. Copper homeostasis. New Phytol, 2009, 182: 799-816

17 Grotz N, Guerinot M L. Molecular aspects of Cu, Fe and Zn homeostasis in plants. Biochim Biophys Acta-Mol Cell Res, 2006, 1763: 595-608

18 Kobayashi Y, Kuroda K, Kimura K, et al. Amino acid polymorphisms in strictly conserved domains of a P-Type ATPase HMA5 are involved in the mechanism of copper tolerance variation in Arabidopsis. Plant Physiol, 2008, 148: 969-980

19 Li W, Lacey R F, Ye Y, et al. Triplin, a small molecule, reveals copper ion transport in ethylene signaling from ATX1 to RAN1. PLoS Genet, 2017, 13: e1006703

20 Deng F, Yamaji N, Xia J, et al. A member of the heavy metal P-type ATPase OsHMA5 is involved in xylem loading of copper in rice. Plant Physiol, 2013, 163: 1353-1362

21 Huang S, Li R, Zhang Z, et al. The genome of the cucumber, Cucumis sativus L. Nat Genet, 2009, 41: 1275-1281

22 Migocka M, Posyniak E, Maciaszczyk-Dziubinska E, et al. Functional and biochemical characterization of cucumber genes encoding two copper ATPases CsHMA5.1 and CsHMA5.2. J Biol Chem, 2015, 290: 15717-15729

23 Oldroyd G E D, Engstrom E M, Long S R. Ethylene inhibits the nod factor signal transduction pathway of Medicago truncatula. Plant Cell, 2001, 13: $1835-1849$

24 Penmetsa R V, Cook D R. A legume ethylene-insensitive mutant hyperinfected by its rhizobial symbiont. Science, 1997, 275: 527-530 
25 Heidstra R W, Yang W C, Yalcin Y, et al. Ethylene provides positional information on cortical cell division but is not involved in Nod factorinduced root hair tip growth in Rhizobium-legume interaction. Development, 1997, 124: 1781-1787

26 Penmetsa R V, Frugoli J A, Smith L S, et al. Dual genetic pathways controlling nodule number in Medicago truncatula. Plant Physiol, 2003, 131: 998-1008

27 Xu M M, Xue X J, Yu Y, et al. Copper ion activates ethylene to inhibit abscisic acid synthesis and enhance potato disease resistance (in Chinese). In: Proceedings of the 2019 Chinese Crop Society Annual Conference, 2019 [许铭铭,薛晓婧, 于悦, 等. 铜离子激发乙烯抑制脱落酸合成增强马 铃薯的抗病性. 见: 2019年中国作物学会学术年会会议论文集, 2019]

28 Binder B M, Rodríguez F I, Bleecker A B. The copper transporter RAN1 Is essential for biogenesis of ethylene receptors in Arabidopsis. J Biol Chem, 2010, 285: 37263-37270

29 Hirayama T, Kieber J J, Hirayama N, et al. RESPONSIVE-TO-ANTAGONIST1, a Menkes/Wilson disease-related copper transporter, is required for ethylene signaling in Arabidopsis. Cell, 1999, 97: 383-393

30 Woeste K E, Kieber J J. A strong loss-of-function mutation in RAN1 results in constitutive activation of the ethylene response pathway as well as a rosette-lethal phenotype. Plant Cell, 2000, 12: 443-455

31 Puig S, Mira H, Dorcey E, et al. Higher plants possess two different types of ATX1-like copper chaperones. Biochem Biophys Res Commun, 2007, 354: $385-390$

\section{补充材料}

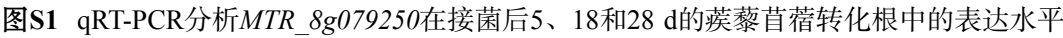

图S2 接菌后 $28 \mathrm{~d}$ 的RNAi转化植株侵染事件统计

图S3 接菌后 $28 \mathrm{~d}$ 的RNAi植株根瘤透射电子显微镜观察

图S4 定量PCR分析MTR_8g079250 RNAi转化植株中结瘤和铜转运相关基因的表达

本文以上补充材料见网络版csb.scichina.com. 补充材料为作者提供的原始数据, 作者对其学术质量和内容负责. 


\title{
Functional analysis of heavy metal transporter HMA5 gene in symbiotic nodulation of Medicago truncatula
}

\author{
Mo Yang ${ }^{\dagger}$, Mingying $\mathrm{Xu}^{\dagger}$, Lu Zhang \& Minxia Chou ${ }^{*}$ \\ Shaanxi Key Laboratory of Agricultural and Environmental Microbiology, State Key Laboratory of Crop Stress Biology in Arid Areas, College of Life \\ Sciences, Northwest A\&F University, Yangling 712100, China \\ $\dagger$ Equally contributed to this work \\ * Corresponding author, E-mail: minxia104@nwafu.edu.cn
}

Leguminous plants are able to grow in a nitrogen-deprived environment because they have evolved a symbiotic relationship with rhizobia in the soil, leading to the formation of new organs, namely nodules. In root nodules, rhizobia reduce nitrogen to ammonia through biological nitrogen fixation and provide ammonia to the host legumes in exchange for carbon source and energy they need. In the symbiosis, legumes also provide the metal trace elements to rhizobia, including copper $(\mathrm{Cu})$. As one of the essential elements for plant growth, $\mathrm{Cu}$ participates in multiple biological processes. However, excess $\mathrm{Cu}$ induces oxidative stress to the detriment of many physiological processes including symbiotic nitrogen fixation. Therefore, the copper content in plants must be maintained within a certain physiological range. The higher plants have evolved complex physiological mechanisms to maintain the copper homeostasis in cells. The heavy metal transporter, Ptype ATPase (HMA), is mainly involved in the transport of heavy metals including copper in plants. All members of the HMA family in the dicot model plant Arabidopsis have been identified and classified. Preliminary research in the laboratory found that HMA5 gene is related to copper stresses and the symbiotic nodulation of Medicago. In this study, the function of HMA5 homologous gene was investigated during symbiotic nodulation in Medicago truncatula (Mt), a model leguminous plant.

A phylogenetic tree was constructed based on the currently classified HMA family genes in Medicago truncatula and the expression patterns of the genes were analyzed. A homologous gene MTR_8g079250 of HMA5 was selected for further study. Subcellular localization assays showed that MTR_8g079250 was localized to the cell membrane and nucleus. The fusion expression analysis of GFP::MTR_8g079250 showed that MTR_8g079250 was mainly expressed in the meristem, infection zone and cortex of the nodules, as well as in the stele and cap of the roots. Knockdown of MTR_8g079250 by RNA interference (RNAi) technology had no significant effect on the symbiotic nitrogen fixation phenotype. However, overexpression of MTR_8g079250 impaired the infection process and nodule development. Compared with the control, the fresh weight and nodule number per plant were dramatically reduced in MTR_8g079250-overexpression plants. The numbers of the infection threads and nodule primordia were also significantly decreased. Ultrastructure analyses showed that the nodule cells contained fewer bacteria in the overexpression plants. In particular, the remarkable deformation of bacteroids and enlargement of peribacteroid space occurred in the infected cells, suggesting premature aging of the nodules. qRT-PCR analyses showed that the expression levels of the nodulation marker genes, NIN, DMI1, ENOD11 and leghemoglobin gene were down-regulated to different extent. These results indicate that the overexpression of MTR_8g079250 inhibited the symbiotic nodulation.

In summary, this study preliminarily assessed the function of HMA5 in symbiotic nodulation, laying a foundation for the subsequent exploration of the absorption, transport and equilibrium mechanisms of copper ions during root nodule symbiosis.

Medicago truncatula, HMA5, symbiotic nitrogen fixation, localization analysis, overexpression doi: 10.1360/TB-2021-0164 